\title{
Impact of Strategic Relationship Marketing on the Performance of Banks in Nigeria
}

\author{
Kolapo, Funso. T. (Ph. D) Ajayi, Omobola. M. (Ph. D) \\ Mokuolu, Joseph. O. (Ph. D) Dada, Samuel. O (Ph. D) \\ Ekiti State University, Department of Finance and Department of Business Administration
}

\begin{abstract}
The increasing patronage of non-bank institutions by customers exerts marketing pressure on the Nigerian commercial banks. Existing studies have not adequately addressed the gap created by this paradigm shift, hence the call for business philosophy that focuses on strategic relationship marketing (SRM) approach with the customers. Therefore, this study examines the influence of the SRM dimensions on customer retention of banks in Nigeria. The sample comprised 1500 commercial bank customers and marketing officers from 300 bank branches in Nigeria. Structured questionnaires were administered for data collection. Hierarchical regression model was fitted to the data collected. The findings revealed that strategic relationship marketing dimensions could lead to increased customer retention with adequate implementation of relationship acquisition strategy, and retention strategy. Further, inclusion of banking industry alignment strategy would make the banks to benefit maximally through customer linkage and also cause an optimal compensation or remedial system. The findings stressed the need for relationship acquisition, relationship maintenance and retention strategy as the strategic marketing tool to enhance customer retention of the banks.
\end{abstract}

Keywords: strategic relationship, marketing, customer retention, banking industry alignment, banks

DOI: $10.7176 / \mathrm{JMCR} / 74-03$

Publication date: December $31^{\text {st }} 2020$

\section{Introduction}

The frontier of marketing management based on understanding of relationship-oriented business life has become an essential need for survival of businesses in recent years. Available evidence shows that customers have diverse economic value to the firms, hence the need for strategic relationship marketing excellence in reaching a level of superior market performance (Reinart, Krafft and Hoyer, 2004). The idea of strategic relationship marketing centres on innovative approach to marketing in the ever-changing market environment based on the understanding of buyer-seller relationship (Hougaard and Bjarre, 2002). In the strategic relationship marketing, a business firm or entity focuses on the overall connection between the customer and the firm, and not just on the individual transaction exchange between them. Therefore, strategic relationship marketing is the ability of a business firm to build and maintain profitable relationships while turning business prospects into customers and customers into business friends/partners. This forms a basis for analysing relationship marketing and developing viable customer strategies most especially in the banking sector.

Over the years, several adversities have befallenthe global financial market, the severity of the effect of these challengesnecessitated the urgent need for an improvement in the operations of banking sectors across Africa and other countries of the world (Gimet and Lagoarde-Segot, 2011; Senbet, 2009).As a result, the number of banks operating effectively in the industry cascaded and the service delivery of the surviving banksreflected a high level of integrated technology, customer satisfaction and an increased level of competition in the banking industry (A $\breve{g} c a$, Nicolò and Detragiache, 2013).In the face of competition, it became increasingly difficult for banks to obtain and retain dominant position and also remain relevant in the market (Kolapo, 2018). There was also severe pressure on bank management to meet performance goals set by stakeholders in a complex, volatile and dynamic economic environment with many of them facing decline in performance (Rose, 1999).For example, the Nigerian banks' performance outlook reflects high level of instability and volatility over the years with return on assets ranging from $2.09 \%, 1.75 \%, 2.67 \%, 2.11 \%, 2.75 \%, 3.8 \%, 0.42 \%, 3.27 \%, 2.05 \%, 1.75 \%, 1.64 \%$ and $2.84 \%$ for years 2005,2006, 2007, 2008, 2009, 2010, 2011, 2012, 2013, 2014, 2015 and 2016 respectively (CBN, 2017).

This means that strategic management decisions should take into consideration factors that promote performance level in terms of customer retention. A prerequisite to this is the need to have a proactive marketing practice. Heskett and Sasser (2010) maintained that the banking systems are becoming increasingly customer dictated and to achieve success requires that they must possess the marketing ability to determine and implement appropriate marketing policy in the right way.

Since banks today now face competition from three dimensions (with themselves within the domestic economy, with non-bank institutions who have suddenly become destination of choice for borrowers and from cross-border financial services providers due to globalization of financial markets, the need to have or exhibit good marketing practices for increased customer retention through relationship marketing becomes desirable. Therefore, banks need to undergo a paradigm shift in marketing practice. According to Li et al (2000) the consensus in the 
literature is that strategic marketing practices provide avenue for utilizing the resources of an organization in order to achieve its set goals and objectives because it enables the adaptation of all the mix elements to environmental forces. Thus, effective relationship marketing in banking is one of the relevant ways to retain customers and enhance performance in a volatile banking sector. The strategies to retain customers include initiating relationship and maintaining such with adequate banking technology and interactions (Williams, Ogege and Ideji, 2014).

Previous studies on relationship marketing have focused on components of relationship strategy, such as the link between satisfaction, loyalty and business performance (Reinartz and Kumar 2000; Kamakura, Mittal, Rosa, and Mazzon. 2002). However, there is a severe lack of research that takes a broader, strategic focus across firms especially in the Nigerian banking sector. There is no clear evidence with respect to the characteristics of successful strategic relationship approaches or the effect a strategic relationship may have. Therefore, it is important to identify the types of strategic relationship marketing dimensions that banks can explore and how they relate to bank performance. To this end, this study conceptualizes and estimates the empirical link between strategic relationship marketing and performance of banks in Nigeria.

\section{Literature Review}

Most of the theoretical approaches in the relationship marketing literature posit that managing relationships is valuable for the performance of firm. A key theoretical basis for strategic relationship marketing research is the buyer-seller interaction. In line with other literature (Brady and Cronin, 2001), the study suggests that each of the dimensions of the strategic relationship marketing process (relationship initiation, maintenance, and termination) has distinct primary sub-dimensions which are customer based. The subsequent dimensions are acquisition and recovery management for the initiation stage; retention, up-selling/cross-selling, and referral management for the maintenance stage while exit management is for the termination stage. These dimensions provide adequate strategic relationship structure for successful marketing plan of an organization. Existing studies on strategic relationship marketing and performance in the banking sector is limited. While only Uche, Ikaba and Nwaneto (2017) studied three micro-finance banks in Nigeria, Kosile and Ajala (2012) focused on three banks in Nigeria, Udeshinni and Ambalam (2013) carried out their study in Kenyan financial sector, Anabila, Narteh and Tweneboah-Koduah (2012) in Ghana, Al-Hersh, Aburoub and Saaty (2014), Ismail (2009) and Ndubisi (2007) in Jordan. All of them examined the nexus between relationship marketing and nonfinancial performance of banks and other financial institutions but could not isolate the effect of strategic relationship marketing on bank performance. Other existing literature Kanti and Dixit (2014), Raza and Rehman (2012); Ismail and Alsadi (2010) and Zhang and Feng (2009) focused on nonfinancial sectors.

Empirical literature on strategic relationship marketing and banks performance is limited and the result of findings on other sectors is mixed and focused basically on customer relationship marketing. Wetosi, Kimutai and Kibet (2017) evaluated impact of relationship marketing strategies on competitive advantage in selected commercial banks in Uasin - Gishu county, Kenya. Primary data were collected using structured questionnaire from 162 sales and 104 marketing employees of the banks using convenience sampling technique. Analysing the data using descriptive and inferential statistics, findings revealed that communication and customer- focused marketing enhanced competitive advantage of the banks. Lian and Liew (2017) examined the influence of relationship quality on customer loyalty in Malaysian telecomm industry. Customer satisfaction, trust, control mutuality and communication were used as the determinants of relationship quality. Structured questionnaires were administered on 405 telecom staff. The data were analysed with descriptive statistics and structural equation modeling. Findings showed that relationship quality had positive effect on customer loyalty. Uche, Ikaba and Nwaneto (2017) evaluated the impact of customer relationship marketing on the performance of three selected micro -finance banks in Nigeria. A survey research design was adopted. A sample of 183 personnel of the banks was taken and data were obtained using five- point likert scale questionnaire titled integrated customer relationship marketing and bank performance. The data were analysed using descriptive statistics and finding shows that integrated customer relationship marketing (ICRM) has significant effect on the performance of micro-finance banks; but the research focus is too narrow to warrant application of findings to the larger banking system in Nigeria.

The study by Al-Hersh, Aburoub and Saaty (2014) examined the impact of customer relationship marketing (CRM) on customer satisfaction of Arab Bank in KSA and Jordan creating two sample pool of respondents. 500 self-administered e-mail questionnaires were circulated and 151 valid responses were obtained. Subjecting the data to descriptive statistical analysis, results revealed medium and high degrees of positive relationship between CRM (trust, commitment, communication, empathy, social bonding) and customer satisfaction of the two samples. Kanti and Dixit (2014) investigated the effect of relationship marketing on the performance of service firms in NCR. The need to collect data from variety of customers from a large population necessitated the use of convenient sampling technique. 100 samples were taken and the data subjected to descriptive statistical analysis. Findings revealed positive significant influence of relationship marketing (measured by service quality, trust, price perception, complaint handling and customer satisfaction) on the performance of service organisations particularly, 
banking and insurance firms. Udeshinni and Ambalam (2013) studied effectiveness of relationship marketing strategieson financial services organizations. The study utilized 100 financial organizations' customers and data were collected through judgmental sampling method from banking, insurance and leasing companies in NuwaraEliya district. Customer perspective (Trust and Communication) and Organization perspectives (information technology) were considered as independent variables and effectiveness of relationship marketing such as competitive advantage and customer satisfaction were considered dependent variables. Employing descriptive and inferential statistical technics, positive relationship was observed between trust and communication (in customer perspective variable) and the effectiveness of organizations. It showed further that positive relationship existed among the inter organization information system, customer relationship management, and data base and the effectiveness. Finally, the correlation between customer perspectives and effectiveness was also observed to be higher than the one between organizations perspectives and effectiveness. Anabila, Narteh and Tweneboah-Koduah (2012) explored the relationship betweenrelationship marketing and customer loyalty in Ghana's banking sector through a data collected using questionnaires from 247 relationship marketing staff of universal banks in Ghana. Reliability test and multiple regression analysis were carried out and the study revealed that the six relationship marketing constructs cumulatively had significant positive effect on customer loyalty. Individually, competence, commitment and communication were found to be significant determinants of customer loyalty. Kosile and Ajala (2012) examined the impact of relationship marketing process on the performance of selected commercial banks in southwestern Nigeria from the dimensions of relationship quality and customer relation benefits. The study employing multi stage random sampling method to obtain qualitative data and analyzed it with SPSS 17.0 version. The result revealed a positive significant relationship between bank performance indicators and relationship marketing. Raza and Rehman (2012) examined the effect of relationship marketing tactics on relationship quality and customer loyalty in Pakistani Telecom industry. Using descriptive statistics and correlation analysis technique, findings revealed that relationship marketing is a strong determinant of customer loyalty. Ismail and Alsadi (2010) studied the effect of RM on the performance of higher educational institutions in Jordan. Using descriptive statistical technique, findings revealed strong positive relationship between organizational performance and relationship marketing. Ismail (2009) investigated the influence of RM on organizational outcomes in insurance industry in Jordan using expert assessment through questionnaire and correlation analysis. Findings showed positive relation between relationship marketing and organizational outcomes in terms of better competitive advantage and increased market share. Zhang and Feng (2009) examined the impact of relationship market tactics on customer loyalty in the Swedish mobile telecom industry. Employing descriptive statistics to analyse the data obtained through online questionnaire, the result revealed that RM tactics (service quality, price perception and value offer) have indirect impact on customer satisfaction and trust; whereas, brand image is positively and directly related to customer loyalty. Ndubisi (2007) explored the effect of relationship marketing strategy on customer loyalty in Malaysian banks. Multiple regression technique was used to analyse qualitative data obtained on key relationship constructs (trust, commitment, communication and customer handling). Findings showed that relationship marketing have significant effect on customer loyalty. Reinartz, Krafft and Hoyer (2004) studied the Customer Relationship Management Process: Its Measurement and Impact on Performance. They employed the use of Hierarchical regression model to analyse the data. It was discovered that Relationship marketing has moderate effect on performance. 


\subsection{Conceptual Framework for Strategic Relationship Marketing and Bank Performance}

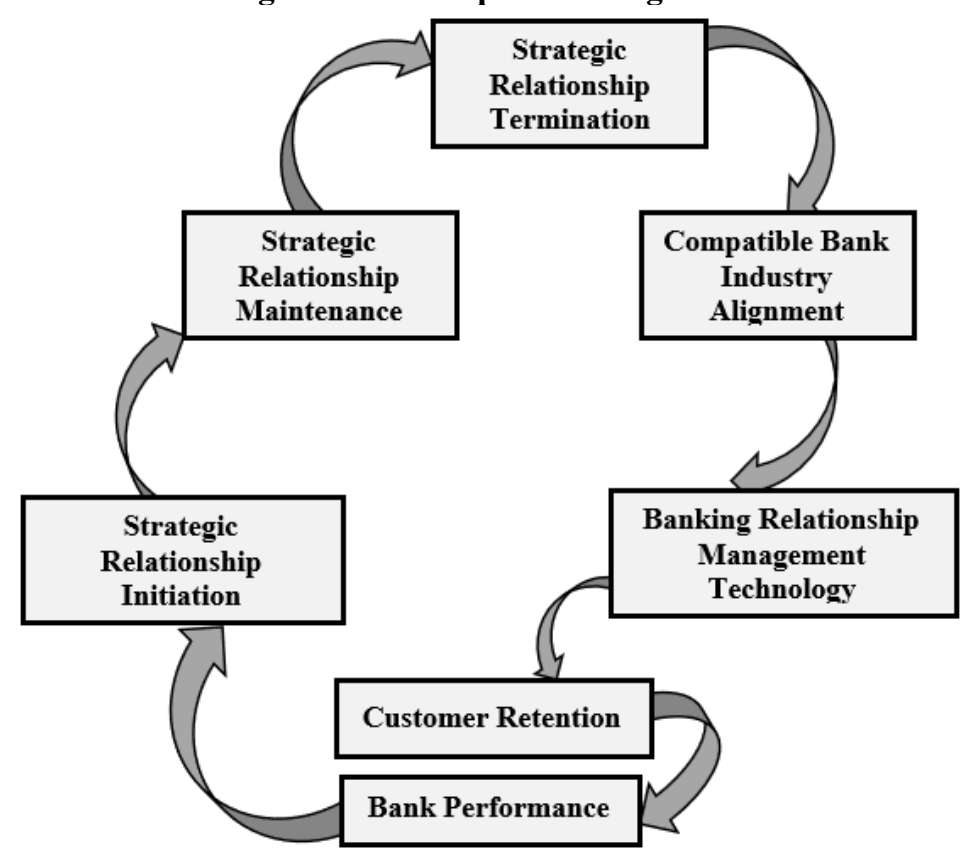

Source: Authors' Construct (2018)

This framework depicts the relationship between the variables analysed in the study. Firstly, strategic relationship initiation is caused and afterwards the bank requires the maintenance of customers relationship, in the process of satisfying and maintaining the interest of customers in the bank, the customers might be less contented and terminates their relationship with the bank. Also, banks at some point might consider or find a customer difficult and employ measures to terminate its relationship with the customer, it is important to note that this situation rarely happens. Meanwhile, a compatible bank industry alignment is occasioned by the ability of banks to maintain and satisfy customers instead of causing the exit of the customers from the bank. This can be attained through an effective relationship management technology, this will cause a good relationship between the banks and their customers and consequently exert a noticeable influence on the performance of banks in Nigeria.

\section{Methodology}

The study covers eight (8) out of the twentyone (21) deposit money banks currently operating in Nigeria. From a total of 1,204 branches of the banks spread across the southwest geopolitical zone in the country, primary data were collected from a sample of 300 bank branches based on Yamane (1967) formula. The managers, financial officers, customers' liaison officers, marketing officers and customers in the bank branches were sampled. Thus a total of 1500 respondents constitute the respondents for the study. Structured questionnaire covering information on strategic relationship marketing was utilized. Data were collected on strategic relationship initiation measured by relationship acquisition and recovery management, strategic relationship maintenance measured by retention, up-selling/cross-selling, and referral management, strategic relationship termination measured by exit management for the termination stage, and compatible banking industry alignment (SBA) is captured by market orientation in corporate functional units, linking customer knowledge and orientation with the firm's goal, development of appropriate compensation schemes, and aligning goals and the employees' utility. Customer retention was used to proxy banks' performance.

\subsection{Model specification}

The model specification for the study is given in Equation 1. Variables are grouped into main effect $(\beta s)$, interaction effect $(\gamma)$ and control variable $(\partial)$. Hierarchical regression model was used to analyse the data following similar study (Reinartz, Krafft, and Hoyer, 2004). The empirical model specification for hierarchical regression to assess the effect of strategic relationships marketing on bank performance is stated hereunder.

$\operatorname{Perf}_{i}=\alpha_{0}$

$+\beta_{1} S R I+\beta_{2} S R M+\beta_{3} S R T+\beta_{4} S B A+\beta_{5} S R G$

$+\gamma 1(S B A x S R I)+\gamma 2(S B A x S R M)+\gamma 3(S B A x S R T)+\gamma 4(S R G x S R I)+\gamma 5(S R G x S R M)+\gamma 6$

$(S R G \times S R T)$

+ ðIBIES

$+\varepsilon_{i}$

Where: 
Perf $=$ Performance (customer retention) measured by using multi-item Likert Scale

$\mathrm{SRI}=$ strategic relationship initiation

$\mathrm{SRM}=$ strategic relationship maintenance

$\mathrm{SRT}=$ strategic relationship termination

SBA = compatible banking industry alignment

$\mathrm{SRG}=$ banking relationship management technology

$\mathrm{BIE}=$ Banking industry effects (Dummy) $\alpha=$

intercept

$\beta_{1-5}=$ parameters to be estimated $\gamma_{1-6}$

$=$ Interaction effects parameters $\varepsilon=$

error term

(i). Strategic relationship initiation (SRI) is measured by relationship acquisition and recovery management. $A$ priori, it is hypothesized that SRI will be positively related to performance. (ii). Strategic relationship maintenance (SRM) is measured by retention, up-selling/cross-selling, and referral management. Positive relationship is also expected between SRM and performance. (iii). Strategic relationship termination (SRT) is measured by exit management for the termination stage. A priori, negative relationship is expected (iv) Compatible banking industry alignment

(SBA) is captured by market orientation in corporate functional units, linking customer knowledge and orientation with the firm's goal, development of appropriate compensation schemes, and aligning company goals and the employees' utility. (v) Relationship management technology (SRG) is another critical moderator of the strategic relationship marketing process-performance link may be the degree to which a firm uses supporting technology. In this context, technology is the information technology that is deployed for the specific purpose of better initiating, maintaining and/or terminating customer relationships.

\section{Results}

\subsection{Descriptive statistics for the measurement scale}

Table 1 shows the descriptive statistics for the measurement scale. Prior to the estimation of hierarchical regression, it is important to assess the relationship between relationship marketing and banks performance in addition to descriptive assessment of the study variables. Thus, the mean and standard deviation of all constructs for relationship marketing variables and nonfinancial performance carried out and the results are presented in Table 1. Based on the descriptive results, the mean level of strategic banking industry alignment is highest $(\mathrm{mean}=4.12$, $\mathrm{SD}=1.18$ ) among other variables of strategic relationships marketing. The mean level of relationship management technology (3.77), strategic relationship initiation (3.70) and relationship maintenance (3.66) constructs could be considered moderate. The standard deviation of all these constructs is lower suggesting suitability of the constructs to explain bank performance.

\section{Table 1: Descriptive statistics for the measurement scale}

\begin{tabular}{|l|r|r|}
\hline & Mean & S.D \\
\hline Perf & & \\
\hline Strategic relationship initiation & 3.68 & \\
\hline 1.Relationship acquisition & 3.71 & 1.29 \\
\hline 2.Recovery management & $\mathbf{3 . 7 0}$ & 1.36 \\
\hline Grand mean & & $\mathbf{1 . 3 3}$ \\
\hline Relationship maintenance & 4.12 & 1.23 \\
\hline 3.Retention & 3.17 & 1.45 \\
\hline 4.Up-selling/cross selling & 3.68 & 1.41 \\
\hline 5.Referral management & $\mathbf{3 . 6 6}$ & \\
\hline Grand mean & & $\mathbf{1 . 3 6}$ \\
\hline Relationship termination & 3.82 & \\
\hline 6.Exit management & & \\
\hline Banking Industry alignment & 3.89 & \\
\hline 7.Market orientation & 4.35 & 1.28 \\
\hline 8. Customer linkage & 4.38 & \\
\hline 9.Compensation scheme & 3.87 & 1.18 \\
\hline 10. Employees utility & $\mathbf{4 . 1 2}$ & 1.11 \\
\hline Grand mean & & $\mathbf{1 . 1 8}$ \\
\hline Relationship management tech. & 3.77 & \\
\hline 11. IT utilization in marketing & & 1.26 \\
\hline Sour Field Survey, 2018 & & \\
\hline
\end{tabular}

Source: Field Survey, 2018 


\subsection{Correlation between strategic relationship marketing and bank performance}

Results of correlations for all variables are also presented in Table 2. Individual constructs relating to strategic relationship initiation and performance show mixed correlation results. The correlation between relationship acquisition $(\mathrm{r}=0.194)$ is positive and significant at $5 \%$. But, the correlation between relationship recovery management is negative $(\mathrm{r}=-0.067)$. The correlation factors reveal positive but weak relationship with the significant construct of retention $(\mathrm{r}=0.135)$ in the relationship maintenance. Relationship termination shows negative relationship ( $\mathrm{r}=-0.135)$ with performance. However, most of the constructs of banking industry alignment such as market orientation (.326), compensation scheme (.218) and employee utility (.141) are positive, moderate and significant except customer linkage (-.03) which is negative but also significant. Relationship between market orientation and performance $(\mathrm{r}=0.326)$ is moderate, positive and significant at $5 \%$ level. The relationship between compensation scheme in the banking industry alignment is also positive $(\mathrm{r}=0.218)$. Meanwhile the relationship between employee utility and performance $(r=0.141)$ is positive, weak but significant ( $5 \%$ level). The results indicate that the relationship could either be negative and positive depending on the measure of between strategic relationship marketing and performance. For example, relationship acquisition is positively related to performance (rho $=0.194$ ) while recovery management shows negative relationship $(r=-0.067)$. But relationship acquisition is significant (5\% level). This shows that increase in marketing effort with focus on strategic relationship acquisition has direct relationship with performance of banks.

Out of the constructs of relationship maintenance, retention strategy is positive and significantly related to performance of bank $(\mathrm{r}=0.135)$, suggesting direct relationship. Meanwhile, upselling/cross selling as a relationship maintenance strategy is negative and significant $(\mathrm{r}=-0.114)$. This implies inverse relationship between the two variables. Strategy to exit relationship shows inverse relationship with performance of banks $(r=-0.135)$. This affirms the need to avoid exiting relationship with customers. All the banking industry alignment is positively related to performance. But, market orientation $(\mathrm{r}=0.326)$ compensation scheme $(\mathrm{r}=0.218)$ and employees unity $(\mathrm{r}=0.141)$ are positive with performance, indicating direct relationship. Relationship management technology is also positively related $(r=0.100)$, highlighting the relevance of IT system in enhancing relationship management and performance of banks.

Table 2: Correlation between strategic relationship and bank performance

\begin{tabular}{|c|c|c|c|c|c|c|c|c|c|c|c|c|}
\hline & Perf & 1 & 2 & 3 & 4 & 5 & 6 & 7 & 8 & 9 & 10 & 11 \\
\hline Perf & 1.00 & & & & & & & & & & & \\
\hline \multicolumn{13}{|l|}{$\begin{array}{l}\text { Strategic } \\
\text { relationship } \\
\text { initiation }\end{array}$} \\
\hline $\begin{array}{l}\text { 1.Relationship } \\
\text { acquisition }\end{array}$ & $.19^{* *}$ & 1.00 & & & & & & & & & & \\
\hline $\begin{array}{l}\text { 2.Recovery } \\
\text { management }\end{array}$ & -.07 & $.19^{* *}$ & 1.00 & & & & & & & & & \\
\hline \multicolumn{13}{|l|}{$\begin{array}{l}\text { Relationship } \\
\text { maintenance }\end{array}$} \\
\hline 3.Retention & $.14^{* *}$ & $.148^{* *}$ & .032 & 1.00 & & & & & & & & \\
\hline $\begin{array}{l}\text { 4.Upselling/cross } \\
\text { selling }\end{array}$ & $-.11^{*}$ & $.15^{* *}$ & .046 & $-.13^{* *}$ & 1.00 & & & & & & & \\
\hline $\begin{array}{l}\text { 5.Referral } \\
\text { Management }\end{array}$ & .04 & $.093^{*}$ & .037 & $-.10^{*}$ & $.174^{* *}$ & 1.00 & & & & & & \\
\hline \multicolumn{13}{|l|}{$\begin{array}{l}\text { Relationship } \\
\text { termination }\end{array}$} \\
\hline $\begin{array}{l}6 . \text { Exit } \\
\text { management }\end{array}$ & $-.14^{* *}$ & $.156^{* *}$ & $.147^{* *}$ & .011 & $.144^{* *}$ & 0.002 & 1.00 & & & & & \\
\hline \multicolumn{13}{|l|}{$\begin{array}{l}\text { Banking Industry } \\
\text { alignment }\end{array}$} \\
\hline 7.Market orientation & $.33^{* *}$ & $-.16^{* *}$ & -.03 & $.13^{* *}$ & $-.10^{*}$ & .075 & $-.13^{* *}$ & 1.00 & & & & \\
\hline $\begin{array}{l}\text { 8. Customer } \\
\text { Linkage }\end{array}$ & -.03 & .07 & .06 & -.069 & $.11^{*}$ & $.097^{*}$ & $.13^{* *}$ & -.01 & 1.00 & & & \\
\hline $\begin{array}{l}\text { 9.Compensation } \\
\text { scheme }\end{array}$ & $.22^{* *}$ & $-.13^{* *}$ & .004 & $.17^{* *}$ & $-.11^{*}$ & .070 & $-.17^{* *}$ & $.27^{* *}$ & .056 & 1.00 & & \\
\hline $\begin{array}{l}\text { 10. Employees } \\
\text { Utility }\end{array}$ & $.14^{* *}$ & -.09 & -.034 & .060 & $.096^{*}$ & $.106^{*}$ & -.018 & $.18^{* *}$ & $.101^{*}$ & $.160 * *$ & 1.00 & \\
\hline \multicolumn{13}{|l|}{$\begin{array}{l}\text { Relationship } \\
\text { management tech. }\end{array}$} \\
\hline $\begin{array}{l}11 . \quad \text { IT } \\
\text { utilization in } \\
\text { marketing }\end{array}$ & $0.10^{*}$ & $0.22^{* *}$ & $0.15^{* *}$ & -.01 & $0.10^{*}$ & 0.08 & $.19^{* *}$ & $-.16^{* *}$ & -.019 & -.08 & $.15^{* *}$ & 1.00 \\
\hline
\end{tabular}

Source: Data Analysis, 2018

$*, * *$, significant at $1 \%$ and $5 \%$, respectively 


\subsection{Effect of strategic relationships marketing on bank performance}

The results of assessment of the effect of strategic relationship marketing on performance using Hierarchical multiple regression model is presented in Table 3. The model was used to test the relationships among the various strategic relationship constructs and performance. The interactions between the strategic relationship constructs were also entered and assessed for their unique contributions to performance outcome of banks. Changes in the multiple squared correlation coefficients for the model and standardized regression coefficients for each variable were examined and the results reflect expectation for good fit of the specification.

The result shows strong support for relationship acquisition as a strategic marketing tool to enhance performance $(\beta=0.636, p<.05)$. In the case of marketing relationship maintenance, retention strategy is crucial to good performance in the market $(\beta=0.455, \mathrm{p}<.05)$ and this is also strongly significant. However, relationship termination does not bode well for good performance $(\beta=0.010, p>.05)$ of banks in the market. Its relationship with perceptual performance is poor and not significant. Thus, it appears that the more firms engage in implementing strategic relationship marketing processes following relationship stages and processes, most especially at strategic marketing initiation and maintenance stages, the better they perform. In the second step of the analysis, the effects of relationship maintenance on banks performance were examined. The results demonstrate a marginal support for marketing relationship maintenance $(\beta=0.386, p<0.05)$ to enhance performance. The positive effect is expected since maintenance of relationship enables the bank to reduce the cost of sourcing for replacement customers and ensure proper planning of marketing agenda. This finding is supported by Reinartz, Krafft and Hoyer (2004). The effect of banking industry alignment through customer linkage was marginally significant for customer linkage $(\beta=0.470, p<0.05)$, and compensation scheme $(\beta=0.278, p<.01)$. The result implies that strategic marketing relationship can have significant effect on performance of banks through continuous marketing alignment in the banking industry. To achieve this, the result points to the need for alignment in the aspect of customer linkage and necessary compensation scheme. This finding suggests that the implementation of strategic relationship management processes is significantly associated with better performance of firms.

In step 3 of the analysis, the result showed significant support for the interaction effects to serve as marketing link to performance of banks. Surprisingly, the results from interaction model significantly supports the need for additional focus on relationship acquisition $(\beta=0.569, \mathrm{t}=2.562, \mathrm{p}<0.05)$ as a relationship initiation strategy and upselling/cross selling to maintain such relationship $(\beta=0.082, p<0.05)$ through existing marketing linkages. Upselling/crossing has the potential to boost performance of banks and help with the achievement of the set objectives. Cross-selling involves offering the bank customer a product or service that is related to whatever they are already used to. This may include promoting a credit card to a savings or current account belonging to a customer. It is expected that such strategy will help keep customers to the products and services offered by the banks. This finding agrees with Jebamani (2015) who established cross selling/upselling as a significant strategy in relationship marketing. Up-selling offers advantage with respect to enabling increase in the quantum placed on an existing product or additional products of banks. The relationship of banking industry alignment to performance is also found to be positive and significant at market orientation stage $(\beta=0.625, p<0.05)$. Interaction effect is significant for interaction between banking industry alignment and relationship initiation $(\beta=0.158, p<0.05)$, and interaction of management technology and relationship maintenance $(\beta=0.039, p<0.05)$. This shows that direct linkagebetween marketing relationship and alignment on one hand, and management technology and relationship maintenance on the other are crucial to enhancing strategic marketing relationship and bank performance. The results affirm significant effect of relationship marketing through interaction between relationship acquisitions, relationship maintenance which centres on retention and upselling/cross selling strategies. Thus, implementation of strategic relationship processes is more likely to improve bank performance especially when the banks develop an effective compensation scheme. Relationship maintenance is more plausible when there is banking industry alignment that focuses on customer linkage and compensation scheme.

The result of hierarchical regression model provides several insights into linkage between strategic relationship marketing and performance of banks. First, the results showed that banks can raise their performance by primarily focusing on strategic relationship initiation and relationship maintenance through relationship acquisition, customer retention and cross selling/upselling. However, the significance of upselling using this approach is not strong. Second, the inclusion of banking industry alignment which includes market orientation, customer linkage, compensation scheme and employees' utility provides another perspective to the relationship marketing-performance linkage. The results showed that for banks to benefit from relationship acquisition and retention, there should be less focus on banking industry alignment constructs (market orientation, customer linkage, compensation scheme and employees' utility) with the exception of upselling/cross-selling. The results showed that cross selling/upselling strategy can best be boosted by simultaneous interaction or inclusion of strategic factors of customer linkage and compensation scheme. 
Table 3: Effect of strategic relationships marketing on bank performance

\begin{tabular}{|c|c|c|c|}
\hline \multirow[b]{2}{*}{ Variable } & \multicolumn{3}{|c|}{ Performance } \\
\hline & Step 1 & Step 2 & Step 3 \\
\hline Intercept & $3.070(8.151)$ & $3.051(6.959)$ & $0.501(0.457)$ \\
\hline \multicolumn{4}{|c|}{ Strategic relationship initiation } \\
\hline Relationship acquisition & $0.636(2.612)^{* *}$ & $0.008(0.132)$ & $0.569(2.562)^{* *}$ \\
\hline Recovery management & $-0.025(-1.690)$ & $0.03(0.073)$ & $0.030(0.636)$ \\
\hline \multicolumn{4}{|l|}{ Relationship maintenance } \\
\hline Retention & $0.455(2.237)^{* *}$ & $-0.056(-1.267)$ & $-0.051(-0.286)$ \\
\hline Up-selling/cross selling & $0.084(1.913)^{*}$ & $0.386(1.968)^{* *}$ & $0.082(1.881)^{*}$ \\
\hline Referral management & $0.040(0.917)$ & $0.050(1.134)$ & $0.016(0.350)$ \\
\hline \multicolumn{4}{|l|}{ Relationship termination } \\
\hline Exit management & $0.010(0.237)$ & $-0.004(-0.098)$ & $-0.018(-0.106)$ \\
\hline \multicolumn{4}{|c|}{ Banking Industry alignment } \\
\hline Market orientation & & $-0.056(-1.118)$ & $0.625(2.355)^{* *}$ \\
\hline Customer linkage & & $0.470(2.516)^{* *}$ & $-0.072(-1.561)$ \\
\hline Compensation scheme & & $0.278(1.752)^{*}$ & $0.73(1.667)^{*}$ \\
\hline Employees utility & & $0.055(1.352)$ & $0.068(1.580)$ \\
\hline \multicolumn{4}{|c|}{ Relationship management tech. } \\
\hline IT utilization in marketing & & $0.028(0.518)$ & $0.043(0.082)$ \\
\hline \multicolumn{4}{|l|}{ Interactions } \\
\hline$S B A \times S R I$ & & & $-0.158(-3.034)^{* *}$ \\
\hline$S B A \times S R M$ & & & $-0.031(-0.770)$ \\
\hline$S B A \times S R T$ & & & $0.028(0.730)$ \\
\hline$S R G \times S R I$ & & & $0.018(0.682)$ \\
\hline$S R G \times S R M$ & & & $0.039(1.863)^{*}$ \\
\hline$S R G \times S R T$ & & & $0.039(1.735)^{*}$ \\
\hline Total $\mathrm{R}^{2}$ & $0.032 * * *$ & $0.146 * * *$ & $0.158 * * *$ \\
\hline$\Delta \mathrm{R}^{2}$ block & $0.032 * * *$ & $0.114 * * *$ & $0.012 * * *$ \\
\hline F-stat & 2.757 & 4.802 & 2.886 \\
\hline P-value & 0.012 & 0.000 & 0.000 \\
\hline
\end{tabular}

Source: Data Analysis, 2018

$* *, *$, significant at $5 \%$ and $1 \%$

\section{Discussion of Findings}

The most consistent and effectual estimation conducted in the study in the bid to examine the impact of strategic relationship marketing on the performance of banks in Nigeria demonstrates that there existsa positive relationship among the pairs of variables used in the study, this undoubtedly reflects an interconnection between the pairs of variables used in the model of the study. Again, results of the regression estimates revealed that strategic relationship initiation (relationship acquisition) exerts a positive noticeable impact on bank performance; this suggests that banks stands the chance ofconsolidating their performance when they go after new customers. However, the maintenance of the initiated or acquired relationship is tantamount to the effectiveness of banks. As a matter of fact, the study ascertained that customer retention and upselling or cross selling significantly influences the performance of banks, this connotes that the persuasion ability as well as the capability to retain customers can cause an unbeatable competitive advantage for banks, thereby shooting up their performance. Furthermore, the result of the estimation revealed that bank industry alignment exerts significant impact on the performance of banks in Nigeria, this illustrates that the activity of aligning the operational and strategic aims of the business through causing an impressive market orientation, customer linkage, compensation or retention scheme for customers and a fair employee utility go a long way in enhancing the performance of banks in Nigeria.

\section{Conclusions and Recommendations}

The studyanalysed the effect of strategic relationship marketing on bank performance. Due to the associated increase in competition in the banking industry, establishing a long-term relationship with customers becomes an important issue for banks. Relationship marketing practices offer banks the opportunity to differentiate themselves from other banks in terms of their marketing practices, such as relationship acquisition, adequate customer linkage and compensation scheme. It is important that banks make use of relationship marketing strategies to provide their customers with a favourable experience in banking, and hence, their satisfaction. This could encourage retention and prevent customers from switching to rival banks. The finding of the study provides adequate information on 
the need for banks to initiate new relationship with new customers, establish adequate relationship maintenance strategy while utilizing relationship management technology to ensure customer satisfaction with their products and services. Also, the finding of the study indicates that the implementation of relationship marketing strategies is associated with performance of banks. The strongest effect is for banks to initiate relationship through acquisition of customers, retention as well as adequate management of combined customer linkage with acquisition strategy.

\section{References}

Ağca, Ş., De Nicolò, G.,\&Detragiache, E., 2013. Banking sector reforms and corporate leverage in emerging markets. Emerging Markets Review, 17, 125-49.

Al-Hersh, A. M., Aburoub, A. S. \&Saaty, A. S. (2014). The impact of customer relationship marketing on customer satisfaction in the Arab bank services. Internationalj Journal of Academic Research in Business and Social Science, 4(5), 67-100.

Anabila, P., Narteh, B., \&Tweneboah-Koduah, E. Y. (2012). Relationship between marketing practices and customer loyalty: Evidence from the banking industry in Ghana. European Journal of Business and Management, 4(13), 51-61.

and the performance of micro -finance banks. Advanced Research Journal of Multidisciplinary Discoveries, 1(60), $36-42$

Brady, M. \& Joseph C. Jr. (2001), "Some New Thoughts on Conceptualizing Perceived Service

Gimet, C., Lagoarde-Segot, T., 2011. Global crisis and financial destabilization in ASEAN countries: A microstructure perspective. Journal of the Asia Pacific Economy, 16 (3), 294-312.

Heskett, J. L., \& Sasser, W. E. (2010). The service profit chain: From satisfaction to ownership, Handbook of Service Science, United Kingdom: Springer.

Hougaard, S., Bjarre, M. \&Hougaard, S. (2004), Strategic Relationship Marketing, Springer, Berlin.

Ismail, S. T. \&Alsadi, B. Y. (2010). Relationship marketing and organizational performance indicators. European Journal of Social Sciences. 12(4), 545-557.

Ismail, S. T. (2009). The effect of relationship marketing on organizational outcomes: An applied study of Jordanian insurance companies. European Journal of Social Sciences, 12(2), 176-184

Kamakura, W. A., Mittal, V., Rosa, F. \&Mazzon, J. A. (2002), "Assessing the Service Profit Chain," Marketing Science, 21 (Summer), 294-317.

Kanti, T. \& Dixit, S. (2014). Impact of relationship marketing on the performance of service companies: An empirical study on NCR. Journal of Business and Management 16(1), 44-53.

Kolapo, F. T. (2018). Effect of strategic marketing practices on the performance of deposit money banks in nigeria. An Unpublished Ph. D. Thesis submitted to the Department of Finance, Ekiti State University, Ado Ekiti. Nigeria.

Kosile, B. A. \&Ajala, O. A. (2012). Relationship marketing and bank performance: An applied study of commercial banks in southwestern Nigeria. European Journal of Business and Management. 4(10), 102-110.

Li, F., Miniard, P. M., \& Barone, M. J. (2000). The facilitating influence of consumer knowledge on the effectiveness of daily value reference information. Journal of the Academy of Marketing Science, 28(3), 425436.

Lian, S. B \& Liew, C. Y. (2017).The effectiveness of strategic relationship marketing: Exploring relationship quality towards customer loyalty. International Business Research; 10(12). 159-166.

Ndubisi, N. O. (2007). Relationship marketing and customer loyalty. Marketing Intelligence and Planning. 25(1), 98-106.

Quality: A Hierarchical Approach," Journal of Marketing, 65, (July) 34-49

Raza, A. \& Rehman, Z. (2012). Impact of relationship marketing tactics on relationship quality and customer loyalty: A case study of telecom sector in Pakistan. African Journal of Business and Management. 6(14), 5085-5092.

Reinartz, W., and Kumar, V. (2000); "On the Profitability of Long-Life Customers in a Non contractual Setting: An Empirical Investigation and Implications for Marketing, Journal of Marketing, 64 (October), 17-35.

Reinartz, W., Krafft, M. \& Hoyer, D. (2004). The Customer Relationship Management Process: Its Measurement and Impact on Performance. Journal of Marketing Research, 41(3), 293305

Rose, P. S. (1999). Commercial bank management (4 ${ }^{\text {th }}$ Ed.). New York: McGraw Hill International Edition.

Senbet, L. W., 2009. Financial Sector Policy Reforms in the Post-Financial Crisis Era: Africa Focus, Working Papers Series $\mathrm{N}^{\circ} 100$, African Development Bank, Tunis, Tunisia. 48 pp.

Uche, D. B., Ikaba, Y. V. \&Nwaneto, U. (2017). Integrated customer relationship marketing

Udeshini, P., \&Ambalam, P. (2013). Impact of promotional strategies on brand. IFRSA Business Review, 3(4), $12-$ 22.

Wetosi, A. W. \&Kimutai, G. (2017). Relationship marketing strategies and competitive advantage in selected commercial banks in Uasin, Gishu County. European Journal of Business, Economics and Accountancy, 5(6), 
$80-86$.

Williams, H.T., Ogege, S., \&Ideji, J.O. (2014), An empirical analysis of effective customers service on nigeria banks profitability. (a queuing and regression approach), Asian Economic and Financial Review 2014, 4(7): 864-876.

Zhang, X. \& Feng, Y. (2009). The impact of customer relationship marketing tactics on customer loyalty: A case study of Swedish mobile telecom industry, Unpublished Master of Business Administration Thesis. Halmstad University. 